\title{
Challenge Based Startup Learning: A Framework to Teach Software Startup
}

\author{
Rafael Chanin $^{1}$, Afonso Sales ${ }^{1}$, Leandro Pompermaier ${ }^{1}$, Rafael Prikladnicki ${ }^{1}$ \\ ${ }^{1}$ PUCRS, School of Technology \\ Av. Ipiranga 6681, Porto Alegre, Brazil \\ rafael.chanin@pucrs.br, afonso.sales@pucrs.br \\ leandro.pompermaier@pucrs.br, rafael.prikladnicki@pucrs.br
}

\begin{abstract}
This paper introduces the Challenge Based Startup Learning, a framework that combines the Challenge Based Learning methodology with Lean Startup and Customer Development concepts, supported by software development techniques. We have applied and evaluated the framework in an undergraduate digital entrepreneurship course. Our preliminary results indicate that students not only understood what it takes to run a real startup, but they also felt engaged and empowered by delivering a useful and meaningful software.
\end{abstract}

Resumo. Este artigo apresenta o Challenge Based Startup Learning, um framework que combina Challenge Based Learning, Lean Startup, e Customer Development, em conjunto com técnicas de desenvolvimento de software. Aplicamos o framework em uma disciplina de graduação - Empreendedorismo Digital. Nossos resultados preliminares mostram que os estudantes não só entendem o processo de criação de uma startup real, mas também se engajam no processo, pois estão entregando um software útil.

\section{Introduction}

Most universities across the world have already recognized the importance of providing entrepreneurial skills to engineer students [Porter et al. 2015]. Being technically competent is a must, but it is not enough. Knowing how to develop, market, and sell products and services is essencial to survive in the reality we live in.

The goal of this paper is to present a framework to educate students on software startups that combines Challenge Based Learning [Nichols et al. 2016], Lean Startup, Customer Development and software development techniques. We call it Challenge Based Startup Learning (CBSL).

\section{The Challenge Based Startup Learning Framework}

The proposed framework is a result of applying the aforementioned methodologies and techniques for two years in an undergraduate digital entrepreneurship course. By doing so, learners not only have the opportunity to develop the necessary technical skills, but they can also connect themselves with potencial users/customers in order to gain real world experience. It is important to point out that the main goal of this framework is not to teach how to develop a successful startup (even though this would be great for students and the community), but to teach the software startup development process. 
Figure 1 presents the Challenge Based Startup Model framework overview. The process starts in the engage phase, where students define their big idea, essential question and the challenge, using design thinking and brainstorming processes. This phase is straightforward and it follows the regular CBL model. It is a critical for students to build engagement and excitement. In the following sprints, students investigate and develop the project by running interviews, testing the value proposition, creating audience and developing prototypes. It is important to mention that reflections occur throughout the whole process. At the end of each sprint, it is fundamental to stop for a few moments in order to document the experience. This material should be used by teachers to improve the process as well as to help students overcome problems and difficulties.

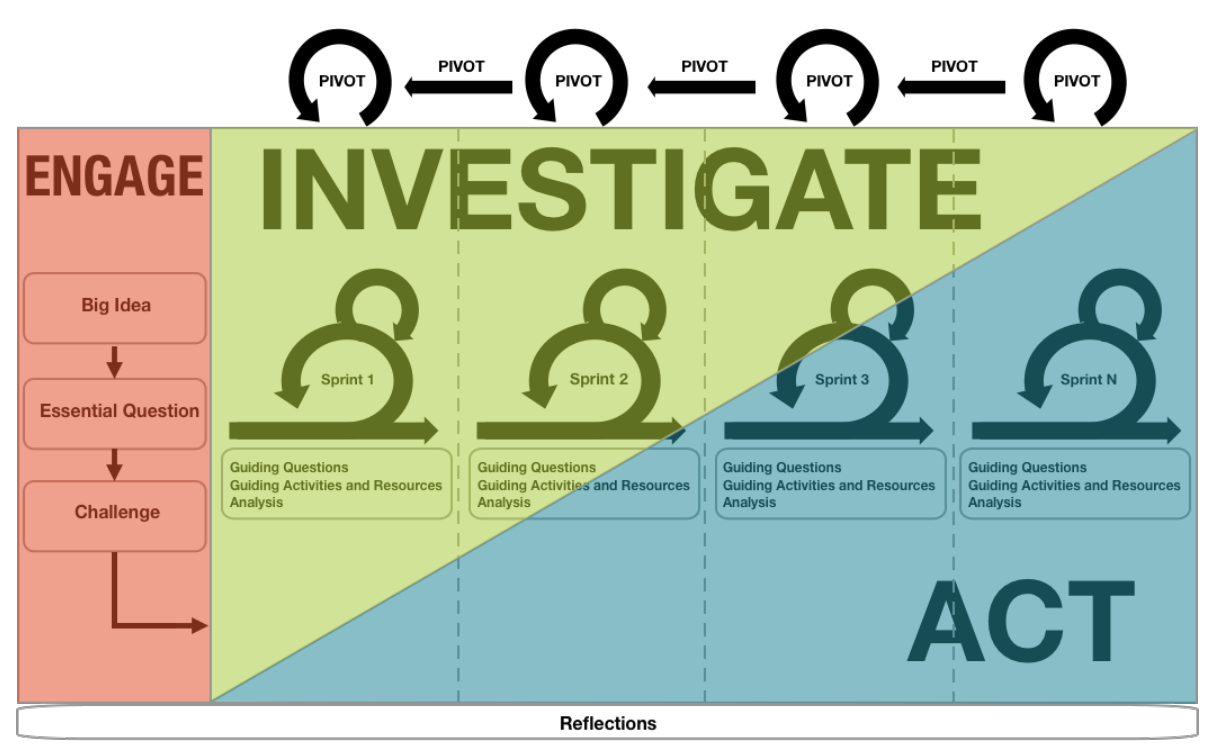

Figure 1. Challenge Based Startup Learning Framework

\section{Conclusions}

The goal of this paper was to present the Challenge Based Startup Learning. Developing a startup requires not only technical skills, but also a lot of soft skills. It is very important for students to understand that they need to explore and learn about customers and their problems. The full paper depicting this work was presented at ITICSE 2018 [Chanin et al. 2018].

\section{References}

Chanin, R., Sales, A., Pompermaier, L., and Prikladnicki, R. (2018). Challenge based startup learning: A framework to teach software startup. In 23rd Annual ACM Conference on Innovation and Technology in Computer Science Education, ITiCSE 2018, pages 266-271, New York, NY, USA. ACM.

Nichols, M., Cator, K., and Torres, M. (2016). Challenge Based Learning Guide. Nichols, M. and Cator, K. and Torres, M., Redwood City, CA, USA.

Porter, J., Morgan, J., Lester, R., Steele, A., Vanegas, J., and Hill, R. (2015). A course in innovative product design: A collaboration between architecture, business, and engineering. In Proceedings of 2015 IEEE Frontiers in Education Conference (FIE), pages 1-5, El Paso, TX, USA. IEEE Computer Society. 